\title{
Examining the Effect of Employee Commitment on Organizational Performance: Evidence from a Cement Manufacturing Company in Nigeria
}

\author{
Darius N. Ikyanyon, PhD \\ Isaac A. Agber, \\ Department of Business Management \\ Benue State University, Makurdi, Nigeria
}

Doi:10.19044/esj.2020.v16n22p78 $\quad$ URL:http://dx.doi.org/10.19044/esj.2020.v16n22p78

\begin{abstract}
In this study, we examined the effect of employee commitment on organizational performance. Employee commitment was conceptualized as a three-dimensional construct comprising affective, continuance and normative commitment. The study therefore examined the effect of each these commitment components on organizational performance using data obtained from 248 respondents drawn from a cement manufacturing company in Nigeria. Data were collected via the use of questionnaires while hypotheses were developed and tested using regression analysis. Findings indicate that while affective and continuance commitment had a significant positive effect on organizational performance, the effect of normative commitment on organizational performance was not significant. Moreover, among these three components of commitment, it was affective commitment that had the most significant positive effect on organizational performance. The study therefore concludes that while employee commitment can influence organizational performance positively, it is the nature of commitment that matters. Given that affective commitment contributes more to organizational performance, we recommend that managers should create enabling work environments that will engender the growth of affective commitment among employees.
\end{abstract}

Keywords: Employee Commitment, Affective, Continuance, Normative, Organizational Performance, Nigeria

\section{Introduction}

The most vital resource any organization can boast of is the human resource. It is the human resource that manages all other material resources; money, materials and machines. Sabir, Majid, Nawal \& Majid (2015) in their opinion supported that human resources are one of the resources of an 
organization that do not only enlarge the efficiency of the organization but also act as a pure source of competitive advantage. Employees are the major composition of the resources in any organization thus, having the potential to ruin or make their unit succeed. Most organizations have realized that the performance of their workers plays a vital role in determining the success of the organization (Zheng, Sharan \& Wei, 2010). As such, it is important for employers and managers alike to know how to get the best out of their workers. In today's competitive business environment, human factors are very significant for enterprises to gain sustainable competitive advantage (Kaplan \& Kaplan, 2018, Qaisar, Rehman \& Suffyan, 2012). Committed employees develop a bond with an organization, which creates better organizational performance. If that emotional connection to their career, relationships with other employees and the organization are present, they perform better and serve the organization better (Andrew, 2017; Yildirim, Acar, Baykaktar \& Akova, 2015). This implies to an extent that the success of an organization is a function of employee commitment. To get employees committed is therefore fundamental to managers, but at the same time challenging as well.

Organizations value commitment among their employees because it is typically assumed to reduce withdrawal behavior, such as lateness, absenteeism and turnover (Irefin\& Mechanic, 2014). Hence, there is no doubt that these values appear to have potentially serious consequences for overall organizational performance. Despite the consensus in acknowledging the benefit of employee commitment to organizational performance, employee commitment is not automatic. Hence, employee commitment has become one of the most popular work attitudes studied by practitioners and researchers. Akintayo (2010) and Tumwesigye (2010) noted that one of the reasons why commitment has attracted research attention is that, organizations depend on committed employees to create and maintain competitive advantage and achieve superior performance.

Today's competitive business environment has made it even more pertinent for organizations to maintain a highly committed workforce. This is because committed employees pull together in one direction to improve their performance at both the individual and team levels (Andrew, 2017). Thus, committed employees are capable of improving the fortunes of the organization through their improved work behaviour. Nevertheless, much of the research in this area has been conducted in developed countries, to the neglect of developing countries (Udu \& Ameh, 2016). To bridge this obvious research gap, the present study seeks to examine the effect of organizational commitment on organizational performance, with particular focus on a cement manufacturing company in Nigeria. 


\section{Employee Commitment}

Employee commitment has been defined as the degree to which the employee feels devoted to their organization (Akintayo, 2010). Moreover, Ongori (2007) describes employee commitment as an affective response to the whole organization and the degree of attachment or loyalty employees feel towards the organization. Meyer and Herscovitch (2001) and Reetta (2018) sees it as a psychological state that binds an employee to an organization thereby reducing the problem of employee turnover and as a mind-set that takes different forms and binds an individual to a course of action that is of important to a particular target.

It is therefore, important to note that all these definitions take into cognizance employees' loyalty and affection. However, employees are committed when they perceived fairness in their psychological contract. Employee commitment is underpinned by social exchange theory, which views the employment relationship as a process of resource exchange governed by the norm of reciprocity (Shore \& Wayne, 1993; Coyle-Shapiro, Kessler, 2000), encompassing both ongoing conferment of benefits and continual re-balancing of expectations and obligations. Perceptions of the mutual obligations held by the employee and the employer may be the result of formal contracts entailed in an employment relationship or implied by the expectations which two parties hold of each other; the latter being captured in the concept of psychological contract (Wang, Indridasson \& Saunders, 2010). Employees reciprocate their employer, based on the extent to which they perceive obligations to them have been fulfilled (Coyle-Shapiro \& Morrow, 2006). The more the employer fulfils obligations and meets expectations, the more employees feel secure and satisfied, and consequently obligated to reciprocate.

Indeed, employee commitment is a crucial factor in achieving organizational success (Ogeniyi, Adeyemi \& Olaoye, 2017; Nasiri, 2017). Individuals with low levels of commitment will do only enough to work. They do not put their hearts into the work and mission of the organization. They seem to be more concerned with personal success than with the success of the organization as a whole. People who are less committed are also more likely to look at themselves as outsiders and not as long - term members of the organization (Irefin \& Mechanic, 2014; Zheng, Sharan \& Wei, 2010). As such, an attractive job offer elsewhere is very likely to result in their departure. In contrast, employees with high commitment to an organization see themselves as an integral part of the organization. Anything that threatens the organization is an imminent danger to them as well. Such employees become creatively involved in the organization's mission and values, and constantly think about ways to do their jobs better (Andrea, 2017. In essence, committed employees work for the organization as if the organization belongs to them. Ajadi and 
Yussuf (2016) opined that committed employees are those who are morally bounded and are not likely to terminate their appointment with the organization prematurely.

Scholars have attempted the classification of commitment as a unidimensional construct thereby treating it as such. Nevertheless, the idea that commitment emanates from different mindsets has heightened the popularity of a multidimensional view of organizational commitment (Meyer \& Allen, 1991). This study aligns itself with the latter view by treating organizational commitment as a multidimensional construct (see Udu \& Ameh, 2016); Sabir, Majid, Nawal \& Majid, 2015); Meyer \& Allen, 1991, 1997 \& 1993). Therefore, employee commitment dimensions considered in this study include: affective, normative and continuance commitment.

Affective commitment measures employees' emotional attachment and participation in the organization. This means that employees love their organization with all their heart. It shows the extent to which the individual identifies with the organization in terms of identification, involvement and emotional attachment. Normative commitment is a feeling of normal obligation to an organization. Employees with high levels of normative commitment feel that they are obliged to remain in the organization (Radosavljevic, Cilerdzic \& Dragic, 2017; Yildirim, Acar, Baykaktar\&Akova, 2015, Umar, 2013). Wiener (1982) pointed out that this sense of obligation to remain in the organization can be realized from the internalization of normative pressures on the individual primarily to approach the organization itself (family or cultural reasons) or from the organizational orientation when influential individuals in the employee environment can exercise strong pressure on the employee to feel a moral responsibility towards the organization (Umoh, Amah \& Wokocha, 2014). Lastly, continuance commitment refers to the awareness of the costs associated with leaving the organization. The potential costs of leaving the organization involve the threat of wasting time and effort spent on the acquisition of non-communicable skills, loss of attractive benefits, waiver of privilege that brings long years of service, and the collapse of family and personal partnerships (Radosavljevic et al, 2017). In addition to costs related to leaving the organization, continuance commitment will also develop in the absence of alternative employment opportunities.

It is worthy to note that key factors can influence an employee's commitment in an organization. These are fairness, trust, concern for employees, affiliation, autonomy, wages and open communication (Kamau, 2015; Igella, 2014; Njenga, Kamau \& Njenga, 2015; Nguyen \& Nguyen, 2014; Coetzee, 2005 and Bragg, 2002). As noted earlier, employee commitment is key to organizational performance. The key issue however is which of the dimensions of commitment has the most significant effect on 
organizational performance. This is one of the issues the present research seeks to unravel.

\section{Organizational Performance}

Organizational performance is the resultant effect of employee commitment levels. The extent of organizational performance is largely enhanced through committed employees. Organizational performance is the essence of existence by which organizations are established. Organizational performance is defined as the attained outcome of actions with the skills of employees who perform in some situation (Prasetya \& Kato, 2011). Organizational performance is a mutual result of effort, ability, and perception of tasks. Organizational performance can be measured using different variables. In this study, we measure performance in term of profitability, productivity, and market share. These measures are not only some of the most popular measures of organizational performance in research, they align with the nature of the organization under investigation.

Profitability entails the ability of an organization to have excess funds after covering its operating expenses in a given period. According to Tulsian (2014) the word profitability is composed of two words, namely, profit and ability. Profit refers to the total income earned by the enterprise during the specified period of time, while profitability refers to the operating efficiency of the enterprise. Simply, it is the ability of the enterprise to make profit on sales. It is the ability of the enterprise to get sufficient return on the capital and employees used in the business operation.

Productivity is a relative concept and firm specific. It is the ratio of input to output. Productivity is commonly defined as a ratio of a volume measure of output to a volume measure of input use. While there is no disagreement on this general notion, a look at the productivity literature and its various applications reveals very quickly that there is neither a unique purpose for, nor a single measure of productivity (Giovanni \& Nezu, 2001).

Market share is also considered a measurement of organizational performance in this study. O'Regan (2002) views market share as a company's sales in relation to total industry sales for a certain period. Market share is usually used to express competitive position. It is also generally accepted that increased market share can be equated with success whereas decreased market share is a manifestation of unfavorable actions by firms and usually equated with failure (Etale, Bingilar \& Ifurueze, 2016).

\section{Effects of Employee Commitment on Organizational Performance}

Different scholars have examined the effects of employee commitment on organization performance in different organizations. This also leads to different views on the construct of employee commitment. Employee 
commitment according to Allen and Meyer $(1984 ; 1990)$ is a tri-dimensional construct which has three components; affective, continuance and normative commitment. It is therefore on the premise that each of the components will be discussed and examined in relation to its effect on organizational performance.

Meyer and Allen (1984: p.375) defined affective commitment as "positive feelings of identification with, attachment to and involvement in the work organization". This shows the extent to which the individual identifies with the organization (identification, involvement, and emotional attachment). Organizational members who are committed to an organization on the basis of this commitment, continue working for the organization because they want to (Meyer \& Allen, 1991). Meyer and Allen (1997) indicated that affective commitment is influenced by factors such as job challenge, role clarity, goal clarity, and goal difficulty, receptiveness by management, peer cohesion, equity, personal importance, feedback, participation, and dependability. As a consequence of positive feelings perceived by the connection with the organization, employees possessing high degrees of affective commitment wish to remain at their organization (Newman \& Sheikh, 2012). The high levels of effort exerted by employees with high levels of affective commitment would lead to higher levels of performance and effectiveness of both the individual and the organizational levels (Sharma \& Bajpai, 2010). This is supported by Allen and Meyer (1990); Beck and Wilson (2000); Meyer and Maltin (2010); Radosavljevic, Cilerdzic and Dragic (2017). It is against this background that we hypothesize that:

$\mathrm{Ho}_{1}$ : There will be a positive effect of affective commitment on organizational performance.

The second component of the tri-dimensional construct is the continuance commitment. Meyer and Allen (1997, p 11) defined continuance commitment as "awareness of the costs associated with leaving the organization". An individual calculates the costs associated with leaving his organization and job amongst job scarcity and his family needs. Meyer and Allen (1991, p. 67) further states that "employees whose primary link to the organization is based on continuance commitment remain because they need to do so" Organizational members remain in an organization because of the gains and rewards for their efforts, and the perceived few chances of getting new jobs (Bandula \& Lakmini, 2016). When given better alternatives, employees may leave the organization. This implies that individuals stay in the organization, because they are lured by other accumulated investments which they could lose such as pension plans, seniority or organization specific skills. By that they put in their best to achieve those benefits. When employees are mindful of the benefits of being in an organization, then they are continually committed and became more involved in achieving the 
organizational missions and visions by improving their job performance (Irefin \& Mechanic, 2014). The cumulative improved in employee job performance will in turn, result in increased organizational performance. This view has been supported by Folorunso, Andewale and Abodunde (2014); Ahmad, Javed and Hamad (2014); Khan, et al (2013). This leads to another hypothesis thus:

$\mathrm{Ho}_{2}$ : There will be a positive effect of continuance commitment on organizational performance.

The third form of commitment among the three dimensions of employee commitment is normative commitment. Meyer and Allen (1997, p 11) defined normative commitment as "a feeling of obligation to continue employment". In this type of commitment, employees feel they ought or should remain in an organization and that it is the right thing to do. The normatively committed employee considers it morally right to stay in the organization, regardless of how much status, enhancement or satisfaction the organization gives him or her over the years. The strength of normative organizational commitment is influenced by accepted rules about reciprocal obligation between the organization and its members (Suliman \& Iles, 2000). This type of commitment is hinged on the social exchange theory, which the individual feels that it is normal to repay the organization. The social exchange theory suggests that a person receiving a benefit is under a strong normative obligation or rule to repay the benefit in some way. Where there is a high level of employee commitment, there will be low turnover and that employee will perform better with less absenteeism (Bandula \& Lakmini, 2016).

The commitment of an individual under this component of commitment depends largely on the organization. This is because the individual tries to reciprocate any organizational behavior towards him, whether good or bad. The basis of this type of commitment is the benefits accomplished by the employees from the organization and his feeling of indebtedness, gratitude and respect to the organization in return for the reciprocal good relations that he/she developed with the organization (Bakhit \& Mohamad, 2017). Employees who have high level of normative commitment feel that they should remain in the organization and work tirelessly to achieving organizational goals. This view has been supported by Kaplan and Kaplan (2018); Udu and Ameh (2016); Irefin and Mechanic (2014). This leads to the hypothesis thus:

Но3: There will be a positive effect of normative commitment on organizational performance. 


\section{Methodology}

\section{Participants}

The participants of this study are comprised of employees drawn from a cement manufacturing company in Nigeria. The participants were approached during breaks at their work stations after we obtained access from the company to conduct the research using their company. In order to maintain high ethical standards, the participants voluntarily accepted to participate in the study while retaining the right to opt out at any point in the course of the study.

Data were collected through the administration of self-completion questionnaire on the participants in the company by the researchers. The questionnaire sought information on the demographic data of respondents and also requesting them to provide responses to issues as it relates to the research. Respondents were required to tick a response from each statement as was applicable to them. A period of one week was given to enable respondents complete the questionnaires upon which the researchers returned to collect completed questionnaires. Out of 300 questionnaires administered, 248 questionnaires were completed and returned which represents a response rate of $82.7 \%$. Considering the challenges of conducting research in a developing country such as Nigeria, this high response rate is encouraging and will enhance the robustness of the data and findings of the research.

\section{Measures}

The measures for this research study were employee commitment and organizational performance. A short version of employee commitment questionnaire developed by Allen, Meyer and Smith (1993) was adapted to measure commitment of employees. This questionnaire has 6 items each measuring affective, continuance and normative commitment. The responses to the questionnaire ranged from strongly disagree to strongly agree. To measure organizational performance, the researchers developed a questionnaire to measure performance indicators of profitability, productivity and market share. The scale also ranged from strongly disagree to strongly agree from which respondents were expected to tick.

\section{Data Analysis and Results}

We present the analysis of data and results obtained below. 
Table 1: Characteristics of the Sample

\begin{tabular}{|c|c|c|}
\hline & Frequencies & Percentage $(\%)$ \\
\hline \multicolumn{3}{|l|}{ Age } \\
\hline $18-25 y r s$ & 58 & 23.4 \\
\hline $26-35 y r s$ & 73 & 29.4 \\
\hline $35-45 y r s$ & 65 & 26.2 \\
\hline 46yrs and above & 52 & 21.0 \\
\hline Total & 248 & $\mathbf{1 0 0 . 0}$ \\
\hline \multicolumn{3}{|l|}{ Gender } \\
\hline Female & 65 & 26.2 \\
\hline Male & 183 & 73.8 \\
\hline Total & 248 & 100.0 \\
\hline \multicolumn{3}{|l|}{ Educational Background } \\
\hline SSCE/GCE & 51 & 20.6 \\
\hline Diploma/NCE & 86 & 34.7 \\
\hline $\mathrm{BSc} / \mathrm{HND}$ & 82 & 33.0 \\
\hline Postgraduate & 29 & 11.7 \\
\hline Total & 248 & 100.0 \\
\hline \multicolumn{3}{|l|}{ Experience } \\
\hline $1-5 y r s$ & 87 & 35.1 \\
\hline $6-10 y r s$ & 58 & 23.4 \\
\hline $11-15 y r s$ & 46 & 18.5 \\
\hline $16-20 y r s$ & 33 & 13.3 \\
\hline Above 20 yrs & 24 & 9.7 \\
\hline Total & 248 & 100.0 \\
\hline
\end{tabular}

The table above indicates that 58 respondents $23.4 \%$ were between the ages of 18-25 years, 73 respondents representing $29.4 \%$ falls between the ages of 26-35 years, 65 respondents representing $26.2 \%$ were between the ages of $35-45$ years while 52 respondents representing $21.0 \%$ were above 45 years old. Also, analyzing the gender of respondents, the table further reveals that 65 respondents representing 26.2\% were male while 183 respondents representing $73.8 \%$ were female employees. More so, the above table the statics for educational background of respondents, the reveals that 51 respondents representing 20.6\% were SSCE/GCE holders, 86 respondents representing $34.7 \%$ were Diploma/NCE holders, 82 respondents representing $33.0 \%$ were B.SC /HND holders and 29 respondents representing $11.7 \%$ had postgraduate qualifications.

Finally, the table shows that 87 respondents representing $35.1 \%$ have worked between 1-5 years, 58 respondents representing $23.4 \%$ have worked between 5-10 years, and 46 respondents representing $18.5 \%$ have worked between 11-15 years. Moreover, 33 respondents representing 13.3\% have worked between 16-20 years while 24 respondents representing 9.7\% have worked above 20 years. 
Regression Results of the Estimated Model Summary

This section presents the results produced by the model summary for further analysis.

Table 2: Model Summary for all variables

\begin{tabular}{|c|c|c|c|c|c|c|c|c|c|c|}
\hline \multirow[t]{2}{*}{ Model } & \multirow[t]{2}{*}{$\mathrm{R}$} & \multirow{2}{*}{$\begin{array}{c}\mathrm{R} \\
\text { Square }\end{array}$} & \multirow{2}{*}{$\begin{array}{l}\text { Adjusted } \\
\text { R Square }\end{array}$} & \multirow{2}{*}{$\begin{array}{l}\text { Std. Error } \\
\text { of the } \\
\text { Estimate }\end{array}$} & \multicolumn{5}{|c|}{ Change Statistics } & \multirow{2}{*}{$\begin{array}{l}\text { Durbin- } \\
\text { Watson }\end{array}$} \\
\hline & & & & & $\begin{array}{l}\text { R Square } \\
\text { Change }\end{array}$ & $\begin{array}{c}\mathrm{F} \\
\text { Change }\end{array}$ & df1 & df 2 & $\begin{array}{c}\text { Sig. F } \\
\text { Change }\end{array}$ & \\
\hline 1 & $\begin{array}{r}.516 \\
\mathrm{a}\end{array}$ & .267 & .257 & 8.26596 & .267 & 28.107 & 3 & 232 & .000 & 1.494 \\
\hline
\end{tabular}

a. Predictors: (Constant), Affective Commitment, Continuance Commitment, Normative Commitment

b. Dependent Variable: Performance

Source: Researcher's Computation using SPSS Version, 20

Table 2 presents the result between employee commitment and the performance of employees. From the model summary table above, the following information can be distilled. The $\mathrm{R}$ value of 0.516 shows that, there is a strong relationship between employee commitment and the organizational performance, however, the $\mathrm{R}^{2}$ stood at 0.267 .The $\mathrm{R}^{2}$ otherwise known as the coefficient of determination shows the percentage of the total variation of the dependent variable performance that can be explained by the independent or explanatory variables (Normative Commitment, Affective Commitment, Continuance Commitment).Thus the $\mathrm{R}^{2}$ value of 0.267 indicates that $26.7 \%$ of the variation in organizational performance can be explained by a variation in the independent variables (affective commitment, continuance commitment and normative commitment) while the remaining $73.3 \%$ (i.e. $100-\mathrm{R}^{2}$ ) could be accounted by other variables not included in this model.

The adjusted $\mathrm{R}^{2}$ of $25.7 \%$ indicates that if the entire population is considered for this study, this result will deviate from it by only 1.0\% (i.e.26.7 $-25.7)$. This result shows that organizational performance is very responsive to employee commitment surrogated by affective commitment, continuance commitment and normative commitment.

The table further shows an F-statistics of 28.107 which indicates that the set of independent variables were as a whole contributing to the variance in the dependent variable and that there exist a statistically significant relationship at $0.000(0 \%)$ between organizational performance and the set of predictor variables (affective commitment, continuance commitment and normative commitment) indicating that the overall equation is significant at $0 \%$ which is below $5 \%$ level of significance. The results of the model summary revealed that, other factors other than employee commitment also contribute high to the variation in organizational performance. 


\section{Regression Coefficient Results}

Regression analysis is the main tool used for data analysis in this study. Regression analysis shows how one variable relates with another. The result of the regression coefficients is here by presented in this section.

Table 3: Coefficients ${ }^{\mathrm{a}}$

\begin{tabular}{|c|c|c|c|c|c|c|c|}
\hline \multirow[t]{2}{*}{ Model } & \multicolumn{2}{|c|}{$\begin{array}{l}\text { Unstandardized } \\
\text { Coefficients }\end{array}$} & $\begin{array}{l}\text { Standardized } \\
\text { Coefficients }\end{array}$ & \multirow[t]{2}{*}{$\mathrm{t}$} & \multirow[t]{2}{*}{ Sig. } & \multicolumn{2}{|c|}{$\begin{array}{l}\text { Collinearity } \\
\text { Statistics }\end{array}$} \\
\hline & B & Std. Error & Beta & & & Tolerance & VIF \\
\hline (Constant) & 35.303 & 3.087 & & 11.435 & .000 & & \\
\hline Affective Commitment & .746 & .130 & .380 & 5.747 & .000 & .721 & 1.387 \\
\hline Continuance Commitment & .611 & .112 & .319 & 5.467 & .000 & .931 & 1.075 \\
\hline Normative Commitment & .019 & .118 & .011 & .159 & .873 & .679 & 1.474 \\
\hline
\end{tabular}

a. Dependent Variable: Organizational Performance

Source: Researcher's Computation using SPSS, Version 20

The regression result as presented in table 3 above to determine the effect of employee commitment variables and organizational performance. The table shows that when employee commitments are not factors to be considered; the performance variables is are estimated at 35.303. This simply implies that when all variables are held constant, there will be a significant increase in organizational performance up to the tune of 35.303 units occasioned by factors not incorporated in this study.

However, the independent variables (affective commitment, continuance commitment and normative commitment) reflect a beta coefficient of $0.380,0.319$ and 0.011 respectively. This thus indicates that a unit change in affective commitment will lead to a significant increase in performance by 0.380 . Similarly a unit change in continuance commitment will lead to a significant increase in performance by 0.319 units. More so, a unit increase in normative commitment will lead to a significant increase in performance by 0.011 units.

It therefore follows from the analysis that affective commitment has been found to have the highest significant positive impact on organizational performance followed by continuance commitment. This means that we accept our first and second hypotheses relating to affective and continuance commitment respectively. Although the effect of normative commitment on organizational performance was positive, the result was insignificant meaning that the third hypothesis is rejected.

\section{Discussion and Conclusion}

This study examined the effect of employee commitment (affective commitment, continuance and normative commitment) on organizational performance in a cement manufacturing company in Nigeria. This study 
succeeds previous studies like Andrew (2017); Tolera (2017); Sabir, Majid, Nawal and Majid (2015) Irefin and Mechanic (2014); Qaisar,Rehman and Suffyan (2012) and several other studies.

In the test of hypothesis one, the standardized beta coefficients at $5 \%$ level of significance was applied to establish whether employees' affective commitment has a significant effect on organizational performance. Data analysis revealed a standardized beta coefficient of 0.380 with a significant value of 0.000 , which is less than the level of significant at 0.05 . This indicates that affective commitment contributes positively and significantly to organizational performance. This finding implies that employees' affective commitment is one of the factors that greatly influence the performance of an organization. Therefore, organizations should create a conducive work environment that will improve the affective commitment of employees as this has the potential to improve the performance of organizations. This finding is in line with the findings of many previous studies that have examined the effect of affective commitment on organizational performance.

More so, the result obtained from testing hypothesis two after applying the standardized beta coefficients at 5\% level of significance to determine whether employees' continuance commitment has a positive effect on organizational performance shows that employees' continuance commitment has a significant effect on organizational performance. The standardized beta coefficient is 0.319 with a significant value of 0.000 , which is less than the level of significance at 0.05 . This finding is in line with results from previous studies that have found a positive effect of continuance commitment on organizational performance (Andrew, 2017; Tolera, 2017). However the finding defies the submission of Kaplan and Kaplan (2018) who found a nonsignificant effect of continuance commitment on performance.

Finally, the result obtained from testing hypothesis three after applying the standardized beta coefficients at 5\% level of significance to determine whether employees' normative commitment has a positive effect on organizational performance shows that employees' normative commitment does not have any significant impact on organizational performance. The standardized beta coefficient is 0.011 with a significant value of 0.873 which is greater than the level of significance at 0.05. This implies that employees' normative commitment is not a factor to be considered in the organization since it does not improve organizational performance. This agrees with the findings of Tutei, Geoffrey and Jared (2017) who established that there was a weak negative relationship between normative commitments and organizational performance.

Based on the foregoing, we therefore, assert that highly committed employees contribute greatly to organizational performance. Nevertheless, the nature of organizational commitment matters since both affective and 
continuance commitment have been found to positively affect organizational performance. Conversely, normative commitment does not significantly affect organizational performance. Given that among the three components of commitment, affective commitment has the most effect on organizational performance, it is therefore pertinent that managers of organizations should concentrate on creating work environments that will boost the affective commitment of employees as this will enable them work towards the attainment of organizational goals and objectives, thereby improving the overall performance of the organization.

This study therefore concludes that the effect of employee commitment on organizational performance depends on the nature of the commitment. Future researchers can extend this line of research by examining the effect of employee commitment on other variables such as job performance, actual turnover, and turnover intentions.

\section{References:}

1. Adekola, B. (2012). The Impact of Organizational Commitment on Job Satisfaction: A study of Employee at Nigerian Universities. International Journal of Human Resources Studies, 2(2),20-29.

2. Akintayo, D. I. (2010). Work-Family Role Conflict and Organizational Commitment among Industrial Workers in Nigeria. Journal of Psychology and Counseling,2(1), 1-8.

3. Andrea, A. B. (2017). Employees' Organizational Commitment and Turnover Intentions, Walden Dissertations and Doctoral Studies Collection, Walden University.

4. Andrew, A. (2017). Employees Commitment and its impact on Organizational Performance. Asian Journal of Economics, Business and Accounting, 5(2), 1-13.

5. Bandula, P. M. K. U. \& Lakmini, J. V. K. (2016). Impact Of Employee Commitment On Job Performance: Based On Leasing Companies In Sri Lanka. International Journal of Arts and Commerce, 5(8), 8-22.

6. Beck, K. \& Wilson, C. (2000). Development of Affective Organizational Commitment. A Cross-sequential Examination of Change with Tenure. Journal of Vocational Behaviour, 56, 114-136.

7. Coetzee, M. (2005). Employee Commitment. Unpublished Thesis submitted to University of Pretoria: University of Pretoria Publishers.

8. Coyle-Shapiro, J. A. M. \& Morrow, P. C. (2006). Organizational and Client Commitment among Contracted Employees. Journal of Vocational Behavior, 68 (2), 416-431.

9. Coyle-Shapiro, J. \& Kessler, I. (2000). Consequences of the Psychological Contract for the Employment Relationship: A large scale survey. Journal of Management Studies,37, 903-930. 
10. Darolia, C. R., Kumari, P. \&Darolia, S. (2010). Perceived Organizational Support, Work Motivation and Organizational Commitment as Determinants of Job Performance. Journal of the Arabian Academy of Applied Psychology, Vol. 36, No. 1, pp. 69-78

11. Etale, L. M., Bingilar, P. F. \&Ifurueze, M. S. (2016). Market Share and Profitability Relationship: A Study of the Banking Sector in Nigeria. International Journal of Business, Economics and Management, 3(8), 103-112

12. Folorunso, O. O., Adewale, A. J. \&Abodunde, S. M. (2014).Exploring the Effect of OrganizationalCommitment Dimensions on Employees Performance: an Empirical Evidence from Academic Staff of Oyo State owned Tertiary Institutions, Nigeri. International Journal of Academic Research in Business and Social Sciences, 4(8).

13. Giovanni, E. \&Nezu, R.(2001). Measuring Productivity: Measurement of Aggregate and Industry-level Productivity Growth. Organization for Economic Co-operation and Development(OECD). Accessed 10/5/2019 at www.sourceOECD.org

14. Hashem, S. J. (2015). An Overview of Organizational Performance Index: Definitions and Measurements.Accessed 07/3/2019at: https://www.researchgate.net/publication/275659514.

15. Igella, R. (2014). Factors influencing Employee Commitment: A case of Kenya Civil Aviation Authority. Unpublished Dissertation submitted to the Chandaria School of Business.

16. Irefin, P. \& Mechanic, M. A. (2014). Effect of Employee Commitment on Organizational Performance in Coca-Cola Nigeria Limited Maiduguri, Borno State IOSR Journal of Humanities and Social Science, 19(3), 33-41.

17. Kamau, W. R. (2015). Factors influencing Employee Commitment and its Impact on Organizational Performance: A case Study of Kenya Airports Authority. Unpublished Master of Business Administration submitted to Chandaria School of Business, United States International University of Africa.

18. Kaplan, M. \& Kaplan, A. (2018). The Relationship between Organizational Commitment and Work Performance: A case of Industrial Enterprises. Journal of Economic and Social Development (JESD), 5(1).

19. Khan, I. Khan, F., Khan, H. \& Nawaz, Y. B. (2013). Determining the Demographic impacts on the Organizational Commitment of Academicians in the HEIS and DCs like Pakistan. European Journal of Sustainable Development, 2(4), 117-130.

20. Khan, M. M., Rehman, Z. \&Akram, M. W. (2012). The impact of Employee Commitment on Employee Satisfaction role of Employee 
Performance as a Moderating Variable. Singapore Journal of Business, Economics and Management Studies, 1(2).

21. Kumari, N. \&Afroz, N. (2013). The impact of Affective Commitment in Employee Life Satisfaction. Global Journal of Management and Business Research Interdisciplinary Vol.13, issue 7.

22. Mathieu, J. E., \& Zajac, D. M. 1990. A Review and Meta-analysis of the Antecedents, Correlates, and Consequences of Organizational Commitment. Psychology Bulletin, 108, 171-194.

23. Meyer, J. P. \& Allen, N. (1984). The Handbook of Employee Engagement: Perspectives, Issues, Research and Practice. Journal of Applied Psychology, 69, 372-378.

24. Meyer, J. P. \& Allen, N. (1991). A three-component conceptualization of organizational commitment. Human Resource Management Review, 1, 61-89.

25. Meyer, J. P. \& Allen, N. (1997). Commitment in the workplace: Theory, research, and application. Thousand Oaks, CA: Sage Publicatioins.

26. Meyer, P. J., Allen, J. N. \& Smith, C. A. (1993). Commitment to Organizations and Occupations: Extension and Test of a ThreeComponent Conceptualization. Journal of Applied Psychology, 78,538-551.

27. Meyer, J. P. \& Maltin, R. E. (2010). Employee Commitment and wellbeing: A Critical Review, theoretical Framework and Research Agenda. Journal of Vocational Behavior 77, 323-337.

28. Nasiri, S. (2017). Human Resource Management, Organizational Commitment and Organizational Performance: Development, Test and Correction of the Causal Model. International Review of Management and Marketing, 7(3), 86-92.

Available at http: www.econjournals.com

29. Negin, M., Omid, M. \&Ahmad, B.M. (2013). The Impact of Organizational Commitment on Employees job performance: A study of Meli Bank. International Journal of Contemporary Research in Business, 5(5), 164-171.

30. Newman, A. \& Sheikh, A. Z. (2012). Organizational Rewards and Employee commitment: A Chinese Study. Journal of Managerial Psychology. 27(1), 71-89.

31. Nguyen, T. \& Nguyen, K. M. (2014). Factors Affecting Employees' Organizational Commitment- A Study of Banking Staff in Ho Chi Minh City, Vietnam . Journal of Advanced Management Science, 2(1) $1-3$.

32. Njenga, G., Kamau, C. \& Njenga, S. (2015). Factors affecting Employees' Commitment to an Organization: A case Study of Jodan 
College of Technology (JCT), Thika. International Journalof Scientific and Research Publications, 5(10).

33. O'Regan, N. (2002). Market Share: the Conduct to Future Success? European Business Review, 14(4), 287-293.

34. Ogeniyi, K. O., Adeyemi, M. A. \& Olaoye, B. O. (2017). Organizational Commitment and Employee's Job Performance: Evidence from Nigerian Hospitality Industry. International Journal of Innovation Psychology and Social Development, 5(3), 15-22.

35. Ongori, H. (2007).A Review of the Literature on Employee Turnover. African Journal of Business Management. 49-54.

36. Prasetya, A., \& Kato, M. (2011). The effect of financial and non financial compensation to the employee performance.Paper presented at the The 2nd International Research Symposium in Service Management.Yogyakarta, Indonesia, 2011.

37. Qaisar, M.U, Rehman, M.S \& Suffyan.M (2012). Exploring Effects of Organizational Commitment on Employee Performance: Implications for Human Resource Strategy. Interdisciplinary Journal of Contemporary Research In Business.3(11), 248 - 255.

38. Reetta, J. (2018). Employee Commitment, how it can be influenced by the Recruitment and Induction Processes of Organizations and what Employees experience to be the Source of the Changes to their Individual Components. Unpublished Thesis submitted to Helsinki Metropolia University of Applied Sciences.

39. Rdosavljevic, Z., Cilerdzic, V. \& Dragic, M. (2017). Employee Organizational Commitment. Faculty of Business Economics and Entrepreneurship International Review, 1-2.

40. Sabir, R. I., Majid, M. B., Nawal, A. \& Majid, A. (2015).Impact of Employee Commitment on Organizational Performance (A survey Based Study on Education Sector of Sahiwal and Okara Pakistan). Scholdge International Journal of Business Policy and Governance, 2(3).

41. Sharma J. P. \& Bajpai, N. (2010). Organizational Commitment and its Impact on Job Satisfaction of Employees: A Comparative Study in Public and Private Sector in India. International Bulletin of Business Administration, 9, 7-19.

42. Tolera, D. G. (2018).Effects of Employees' Commitment on organizational Performance at ArjoDidessa Sugar Factory.African Journal of Business Management, 12(9), 252-257.Available athttp://www.academicjournals.org/AJBM.

43. Tulsian, M. (2014). Profitability Analysis (a Comparative Study of SALL \& TATA Steel). IOSR Journal of Economics and Finance, 3(2), 19-22 
44. Tumwesigye, G. (2010) The Relationship between Perceived Organizational Support and Turnover intentions in a Developing Country: The Mediating Role of Employee Commitment. African Journal of Business Management. 4(6), 942-952.

45. Tutei, A.H. K, Geoffrey, K. \& Jared, B. (2017). Continuance Commitment and Employee Performance at University of Eastern Africa, Baraton Kenya.Scholarly Journal of Science Research and Essay, 6(5), 114-120. Available at http://www.scholarly ournals.com/SJSRE.

46. Udu, A. A. \& Ameh, A. A. (2016). Effects of Employee Commitment on Organizational Performance in the Banking Industry: an Evidence from First Bank Zonal Office. Journal of Business Administration, 6 (1), 1-7.

47. Umar, G. (2013). Employee Commitment and Performance of Manufacturing Firms. JORIND, 11(1). Available online at www.transcampus.org/journals; www.ajol.info/journals/jorind.

48. Umoh, G. I., Amah, E. \&Wokocha, I. H. (2014). Employee Benefits and Continuance Commitment in the Nigerian Manufacturing Industry. IOSR Journal of Business and Management, 16(2), 6774.

49. Wang, C. L., Indridasson, T. \& Saunders, M. N. K. (2010). Affective and Continuance Commitment in Public Private Partnership. Employee Relations, 32(4),396-417.

50. Wiener, Y. (1982). Commitment in Organizations: A normative view. The Academy of Management Review, 7(3), 418-428.

51. Yavuz, D. \&Kubilayhan, G. (2013). The Impact of Organizational Commitment on Knowledge Sharing. Proceedings from $1^{\text {st }}$ Annual International Interdisciplinary Conference, AIIC Azores, Portugal, 2013, 24-26.

52. Yildirim, M., Acar, A. G., Baykaktar, S. U. \& Akova, O. (2015). The effect of Organizational Commitment to intention to leave Employment: A Research in Hotel Management. International Journal of Business and Social Science,6(11).

53. Zheng, W., Sharan, K. \& Wei, J. (2010). New Development of Organizational Commitment: A Critical Review (1960-2009). African Journal of Business and Management, 4(1), 12-20. 